\title{
THE ZONA REACTION OF HAMSTER AND MOUSE EGGS: PRODUCTION IN VITRO BY A TRYPSIN-LIKE PROTEASE FROM CORTICAL GRANULES
}

\author{
R. B. L. GWATKIN, D. T. WILLIAMS, J. F. HARTMANN \\ AND M. KNIAZUK \\ Merck Institute for Therapeutic Research, \\ Rahway, New Jersey 07065, U.S.A.
}

(Received 4th Fanuary 1972)

\begin{abstract}
Summary. The cortical granules of hamster ova were ruptured in vitro by electrical stimulation (standard treatment was $150 \mathrm{~V}, \mathrm{l} .0 \mathrm{msec}$ ). Approximately $8 \mathrm{~min}$ were required for the cortical granule material so released to induce a complete zona reaction. The active material from the cortical granules was released into the medium from vitelli and was shown to act directly on the zona pellucida and on mouse, as well as on hamster, ova, i.e. its action is not species specific. The action of the cortical granule material was reversed by trypsin inhibitors. Such a trypsin-like protease, causing the zona reaction, was also released from vitelli by spermatozoa.
\end{abstract}

\section{INTRODUCTION}

The zona reaction, a sperm-induced change in the zona pellucida which blocks further sperm penetration into the eggs, was first described in mammals 18 years ago by Braden, Austin \& David (1954). Cortical granules were reported to disappear from the surface of the vitellus and it was surmised that breakdown of these granules released a substance which rendered the zona pellucida impenetrable to spermatozoa (Austin \& Braden, 1956). Recently, Barros \& Yanagimachi (1971) strengthened this hypothesis by blocking the fertilization of hamster eggs with cortical granule material released from the vitellus by sperm penetration. The nature of this agent and how it might act, however, were not determined.

In this paper, evidence is presented to show that cortical granule material from hamster vitelli, released into the medium either by electrical stimulation or by spermatozoa, induces the zona reaction by means of a trypsin-like protease. This is consistent with our recent demonstration that capacitated hamster spermatozoa adhere to the zona pellucida by a receptor which is sensitive to trypsin (Hartmann \& Gwatkin, 1971).

\section{MATERIALS AND METHODS}

Eggs were obtained as described previously (Gwatkin, Andersen \& Hutchison, 
1972) from the oviducts of superovulated golden hamsters, Mesocricetus auratus, 17 to $20 \mathrm{hr}$ after an injection of HCG. The cumulus oophorus was removed by a 5-min exposure to hyaluronidase (450 USP units/ml Dulbecco's phosphatebuffered saline). To prepare vitelli, the zona pellucida was removed with pronase (Gwatkin, 1971). Isolated zonae pellucidae were obtained by pipetting the eggs rapidly back and forth by means of a micropipette with an orifice slightly too small to accommodate an egg (Gwatkin, 1966). Spermatozoa were obtained from the cauda epididymidis (Gwatkin \& Williams, 1970) and capacitated in vitro with oviduct contents (Gwatkin et al., 1972).

Eggs and vitelli were electrically stimulated in 10- or 20- $\mu$ l drops of medium 199M (Gwatkin \& Williams, 1970) under mineral oil on the bottom of a plastic Petri dish ( $6 \mathrm{~cm}$ diameter), by means of electrodes made from No. 30 gauge needles. The stimuli were obtained either from a charged capacitor, or a stimulator (Grass Instruments, Quincy, Mass., U.S.A.) set to deliver monophasic square wave pulses of varied amplitude and duration.

Cortical granules were observed by mounting the eggs on a slide, compressing them slightly beneath a vaseline-edged cover glass and examining the uppermost surface with a phase-contrast microscope equipped with an oil-immersion objective. Resistance of the treated eggs to penetration by capacitated spermatozoa was determined by adding an equal volume of sperm suspension ( 1 to $3 \times$ $10^{7}$ motile spermatozoa $/ \mathrm{ml}$ ) to the $20-\mu$ l drops containing the eggs. The dish containing the drops was incubated at $37^{\circ} \mathrm{C}$ on a rocker (five to six oscillations/ $\mathrm{min}$ ) for $90 \mathrm{~min}$. The eggs were then transferred to a slide and examined for passage of sperm heads through the zona pellucida and sperm penetration into the vitellus as described previously (Gwatkin et al., 1972).

\section{RESULTS}

Both capacitor discharges and monophasic square wave pulses were administered to groups of twenty eggs in 20- $\mu$ l drops of medium under oil, by means of electrodes placed directly into the drops on either side of the eggs. After incubation at $37^{\circ} \mathrm{C}$ for $60 \mathrm{~min}$, capacitated spermatozoa were added in an equal volume of medium. Adherence of the spermatozoa and their penetration through the zona pellucida were scored $90 \mathrm{~min}$ later. The results are summarized in Table 1 .

A $0 \cdot 5-\mu \mathrm{F}$ and a $60-\mu \mathrm{F}$ capacitor, charged to 50 and $10 \mathrm{~V}$, respectively, and discharged across the eggs were sufficient to block sperm entry. The latter also blocked completely the adherence of spermatozoa to the eggs. A $2 \cdot 0-\mu \mathrm{F}$ capacitor charged to $150 \mathrm{~V}$ caused necrosis of the eggs, manifested by a brownish discoloration and expansion of the vitellus. Square wave pulses of $40 \mathrm{~V}$ with $1.0 \mathrm{msec}$ duration and $50 \mathrm{~V}$ with $0.1 \mathrm{msec}$ duration also blocked penetration. Adherence was not blocked completely until $150 \mathrm{~V}$ were delivered for $1.0 \mathrm{msec}$. Prolonged stimulation ( $20 \mathrm{~V}$ for $100 \mathrm{msec}$ or $40 \mathrm{~V}$ for $50 \mathrm{msec}$ ) produced necrosis.

Capacitor discharges $(20 \mathrm{~V}, 60 \mu \mathrm{F})$ through the medium alone, before the addition of ova, did not affect sperm adherence or penetration, nor did the same stimulation of isolated zonae pellucidae affect the adherence of sperma- 
Table 1. Effect of electrical stimulation of hamster eggs on adherence and penetration of capacitated spermatozoa

\begin{tabular}{|c|c|c|c|c|c|}
\hline \multicolumn{3}{|c|}{ Electrical stimulation } & \multirow[b]{2}{*}{$\begin{array}{c}\text { Appearance } \\
\text { of eggs }\end{array}$} & \multicolumn{2}{|c|}{ Percentage of eggs with: } \\
\hline $\begin{array}{c}\text { Voltage } \\
(V)\end{array}$ & $\begin{array}{c}\text { Capacitance } \\
(\mu F)\end{array}$ & $\begin{array}{c}\text { Duration } \\
\text { (msec) }\end{array}$ & & $\begin{array}{l}\text { Adherent } \\
\text { sperm. }\end{array}$ & $\begin{array}{c}\text { Penetration } \\
\text { by sperm. }\end{array}$ \\
\hline 0 & & & Normal & 100 & 100 \\
\hline $\begin{array}{l}50 \\
50\end{array}$ & $\begin{array}{l}0.1 \\
0.5\end{array}$ & & $\begin{array}{l}\text { Normal } \\
\text { Normal }\end{array}$ & $\begin{array}{r}100 \\
10\end{array}$ & $\begin{array}{r}100 \\
0\end{array}$ \\
\hline $\begin{array}{l}150 \\
150\end{array}$ & $\begin{array}{l}0.5 \\
2.0\end{array}$ & & Normal & 20 & 0 \\
\hline $\begin{array}{r}5 \\
10 \\
20 \\
40\end{array}$ & $\begin{array}{l}60.0 \\
60 \cdot 0 \\
60 \cdot 0 \\
60 \cdot 0\end{array}$ & & $\begin{array}{l}\text { Necrotic } \\
\text { Normal } \\
\text { Normal } \\
\text { Normal } \\
\text { Normal }\end{array}$ & $\begin{array}{r}100 \\
0 \\
0 \\
0\end{array}$ & $\begin{array}{r}100 \\
0 \\
0 \\
0\end{array}$ \\
\hline $\begin{array}{l}20 \\
20 \\
20\end{array}$ & & $\begin{array}{r}1 \cdot 0 \\
50 \cdot 0 \\
100 \cdot 0\end{array}$ & $\begin{array}{l}\text { Normal } \\
\text { Normal } \\
\text { Necrotic }\end{array}$ & $\begin{array}{r}100 \\
20\end{array}$ & $\begin{array}{r}100 \\
0\end{array}$ \\
\hline $\begin{array}{l}40 \\
40\end{array}$ & & $\begin{array}{r}1.0 \\
50.0\end{array}$ & $\begin{array}{l}\text { Normal } \\
\text { Necrotic }\end{array}$ & 50 & 0 \\
\hline $\begin{array}{l}10 \\
50\end{array}$ & & $\begin{array}{l}0.1 \\
0.1\end{array}$ & $\begin{array}{l}\text { Normal } \\
\text { Normal }\end{array}$ & $\begin{array}{r}100 \\
35\end{array}$ & $\begin{array}{r}80 \\
0\end{array}$ \\
\hline $\begin{array}{l}150 \\
150\end{array}$ & & $\begin{array}{l}0.1 \\
1.0\end{array}$ & $\begin{array}{l}\text { Normal } \\
\text { Normal }\end{array}$ & $\begin{array}{r}29 \\
0\end{array}$ & $\begin{array}{l}0 \\
0\end{array}$ \\
\hline
\end{tabular}

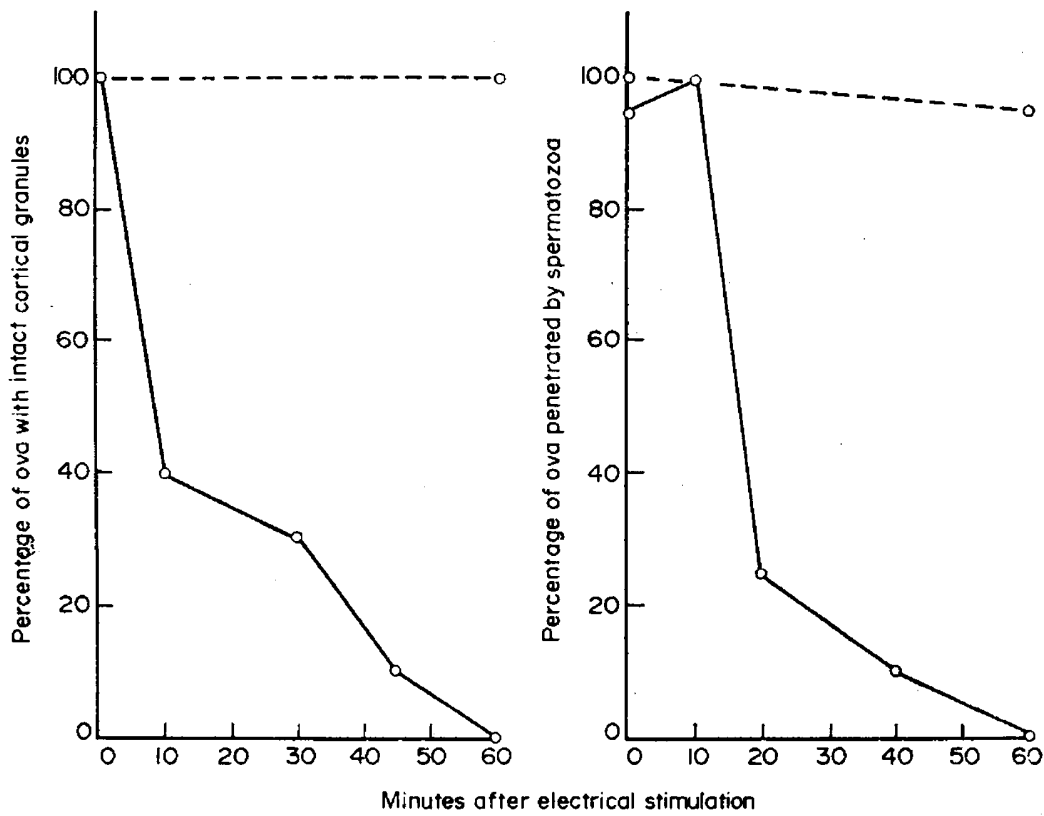

Text-Fig. 1. The rate of disappearance of cortical granules from the vitelline surface compared with the rate of acquired resistance by golden hamster ova to penetration by spermatozoa. 
tozoa to them. Thus, the electrical stimulation appeared to be acting through the vitellus. The rate of disappearance of cortical granules from the vitelline surface was next examined by oil-immersion phase-contrast microscopy and compared with the rate of loss in sperm penetration (Text-fig. 1). Approximately $8 \mathrm{~min}$ were required for $50 \%$ of the eggs to lose cortical granules, while approximately $16 \mathrm{~min}$ were required for $50 \%$ of the eggs to resist sperm entry. Hence, it would appear that a period of about $8 \mathrm{~min}$ is needed for the cortical granule product to produce the zona reaction. Approximately $60 \mathrm{~min}$ were required for the entire group of eggs to release their cortical granules and to undergo a complete block to sperm entry.

The possibility of releasing a sufficient quantity of material from the cortical granules so that it could be assayed on other eggs was also explored. After removal of the zona pellucida with pronase, groups of 150 washed vitelli were placed in $10-\mu 1$ drops, and $50 \%$ of the drops were electrically stimulated $(150 \mathrm{~V}$ for $1 \mathrm{msec}$ ) while the other $50 \%$ served as controls. To avoid possible heat inactivation of the cortical granule product, the cultures were incubated at

Table 2. Induction of the zona reaction by electrically stimulated vitelli

\begin{tabular}{|c|c|c|c|c|c|}
\hline \multirow[b]{2}{*}{ Test object } & \multirow[b]{2}{*}{$\begin{array}{l}\text { Treatment } \\
\text { of vitelli }\end{array}$} & \multicolumn{2}{|c|}{ Sperm adherence } & \multicolumn{2}{|c|}{ Sperm penetration } \\
\hline & & $\begin{array}{l}\text { \% ova } \\
\text { or zonae with } \\
\text { sperm. adherent }\end{array}$ & $\begin{array}{l}\text { Mean no. of } \\
\text { sperm. adherent } \\
\text { lovum or zona }\end{array}$ & $\begin{array}{c}\% \text { ova } \\
\text { penetrated }\end{array}$ & $\begin{array}{l}\text { Mean no. of } \\
\text { sperm. /ovum }\end{array}$ \\
\hline Hamster ova & $\begin{array}{l}\text { Unstimulated } \\
\text { Stimulated }\end{array}$ & $\begin{array}{r}100 \\
0\end{array}$ & $\begin{array}{l}3 \cdot 2 \\
0\end{array}$ & $\begin{array}{r}100 \\
0\end{array}$ & $\begin{array}{l}2 \cdot 7 \\
0\end{array}$ \\
\hline $\begin{array}{l}\text { Hamster zonae } \\
\text { pellucidae }\end{array}$ & $\begin{array}{l}\text { Unstimulated } \\
\text { Stimulated }\end{array}$ & $\begin{array}{r}100 \\
0\end{array}$ & $21 \cdot 0$ & & \\
\hline Mouse ova & $\begin{array}{l}\text { Unstimulated } \\
\text { Stimulated }\end{array}$ & $\begin{array}{r}75 \\
0\end{array}$ & $\begin{array}{l}2 \cdot 6 \\
0\end{array}$ & $\begin{array}{r}30 \\
0\end{array}$ & $\begin{array}{l}1 \cdot 0 \\
0\end{array}$ \\
\hline
\end{tabular}

room temperature $\left(22^{\circ} \mathrm{C}\right)$. After $60 \mathrm{~min}$, during which the cortical granules of the stimulated eggs were observed to rupture, hamster eggs, isolated hamster egg zonae pellucidae and mouse eggs were added to the treated and to the control drops. The drops were then incubated again at room temperature for an additional $120 \mathrm{~min}$. At the end of this period, the eggs and zonae pellucidae were washed (by transferring them through three $0.5-\mathrm{ml}$ vols of medium) and exposed to capacitated spermatozoa. Table 2 shows that cortical granule material acted directly on the zona pellucida, altering it so that capacitafed spermatozoa could not adhere. The effect is clearly not species specific, since hamster cortical granule material was effective on mouse eggs.

For the reasons mentioned in the introduction to this paper, it appeared likely that the active factor from the cortical granules was a trypsin-like protease. The effect of trypsin inhibitors on the active material released by electrically stimulated vitelli $(150 \mathrm{~V}$ for $1 \mathrm{msec})$ was therefore determined. The inhibitors were added to the drops just before adding the test eggs. Both soybean trypsin inhibitor and $p$-aminobenzamidine, a low molecular weight trypsin inhibitor (Mares-Guia \& Shaw, 1965), effectively blocked the action of cortical 
granule material (Table 3). These data indicate that the active factor from cortical granules is a trypsin-like enzyme.

To determine whether the factor obtained by electrical stimulation was the same as that released on sperm entry, groups of 600 vitelli were placed in $20-\mu 1$ drops and combined with equal volumes of either capacitated spermatozoa $\left(2 \times 10^{7}\right.$ motile spermatozoa $\left./ \mathrm{ml}\right)$ or medium. Parallel drops were prepared containing sperm suspension and medium alone. After $60 \mathrm{~min}$, the contents of these drops were transferred to a test-tube and centrifuged at $1000 \mathrm{~g}$ for $10 \mathrm{~min}$. The supernatants (confirmed free of vitelli and spermatozoa by

Table 3. Effect of trypsin inhibitors on the zona reaction in hamster eggs induced by electrically stimulated vitelli

\begin{tabular}{l|c|c|c}
\hline \multirow{2}{*}{ Enzyme inhibitor } & \multicolumn{2}{c}{ Percentage of ova } \\
\multicolumn{1}{c|}{ Type } & Conc. $(\mu \mathrm{g} / \mathrm{ml})$ & $\begin{array}{c}\text { With sperm } \\
\text { adherent }\end{array}$ & $\begin{array}{c}\text { Penetrated } \\
\text { by sperm. }\end{array}$ \\
\hline None & & 5 & 5 \\
Soybean & 100 & 80 & 65 \\
& 500 & 100 & 75 \\
p-Aminobenzamidine & 20 & 75 & 65 \\
& 100 & 80 & 65 \\
\hline
\end{tabular}

Table 4. Effect of soybean trypsin inhibitor on the zona reaction in hamster eggs induced by cortical granule product released from vitelli by spermatozoa

\begin{tabular}{|c|c|c|c|c|}
\hline \multirow[b]{2}{*}{$\begin{array}{l}\text { Material tested for induction of } \\
\text { zona reaction }\end{array}$} & \multicolumn{2}{|c|}{ Sperm adherence } & \multicolumn{2}{|c|}{ Sperm penetration } \\
\hline & $\begin{array}{c}\% \text { ova with } \\
\text { sperm. adherent }\end{array}$ & $\begin{array}{l}\text { Mean no. of sperm. } \\
\text { adherent/ovum }\end{array}$ & $\begin{array}{c}\% \text { ova } \\
\text { penetrated }\end{array}$ & $\begin{array}{l}\text { Mean no. of } \\
\text { sperm. /ovum }\end{array}$ \\
\hline \multirow{3}{*}{$\begin{array}{l}\text { Supernatant from sperm. } \\
\text { Supernatant from vitelli, } \\
\text { unexposed to sperm. } \\
\text { Cortical granule product } \\
\text { Cortical granule product }+ \text { Soybean } \\
\text { trypsin inhibitor ( } 1 \mu \mathrm{g} / 10-\mu \mathrm{l} \text { drop) }\end{array}$} & 100 & $5 \cdot 3$ & 100 & $2 \cdot 5$ \\
\hline & $\begin{array}{r}100 \\
0\end{array}$ & $\begin{array}{l}3.4 \\
0\end{array}$ & $\begin{array}{r}100 \\
0\end{array}$ & $\begin{array}{l}2 \cdot 6 \\
0\end{array}$ \\
\hline & 100 & $5 \cdot 2$ & 100 & $2 \cdot 2$ \\
\hline
\end{tabular}

microscopic examination) were used to prepare new 10- $\mu$ l drops. Soybean trypsin inhibitor ( $1 \mu \mathrm{g}$ in $1 \mu \mathrm{l}$ medium) was added to some of these drops, while the rest received an equal volume of medium only. Fresh eggs were then added and after incubation for $60 \mathrm{~min}$, these eggs were washed, exposed to capacitated spermatozoa for $90 \mathrm{~min}$ and scored for sperm penetration. From Table 4, it is clear that the spermatozoa liberated a substance from the vitelli which blocked sperm penetration and was inhibited by soybean trypsin inhibitor.

\section{DISCUSSION}

These experiments indicate that the zona reaction is produced by a trypsin-like 
protease liberated from the cortical granules. The protease presumably attacks the species-specific receptor-for-spermatozoa on the zona pellucida. This receptor was earlier shown to be sensitive to very low concentrations of trypsin (Hartmann \& Gwatkin, 1971). The fact that, following the zona reaction, the zona pellucida of the hamster egg shrinks markedly on fixation with gluteraldehyde (R. B. L. Gwatkin, unpublished observation) and that the time required for dissolution of the mouse zona pellucida by proteolytic enzymes (Smithberg, 1953 ), and by crude $\beta$-glucuronidase (Gwatkin, 1964) suggests some component of the zona pellucida is removed during the reaction.

Conrad, Buckley \& Stambaugh (1971) have proposed an alternative hypothesis, namely that the block to polyspermy is due to a direct effect of a hypothetical cortical granule inhibitor on the trypsin-like protease of the spermatozoa, but they have not presented any supporting evidence to justify their concept. Their demonstration that the zona pellucida of the rabbit egg is more resistant to trypsin after fertilization is not relevant, since there is no zona reaction in this species. Their hypothesis also appears unlikely in view of the known effect of cortical granule products on the zona pellucida and the evidence presented here for a cortical granule protease. Furthermore, such an inhibitor, if it existed, would be working at cross-purposes, facilitating and blocking sperm entry simultaneously; an unlikely possibility.

Our exploration of electrical stimulation for the rupture of cortical granules was based on the report of Tarkowski, Witkowska \& Nowicka (1970), which showed that electrical stimulation of the mouse oviduct would cause parthenogenesis of the eggs within it. We supposed that such activation of the eggs might also lead to cortical granule breakdown, which in fact proved to be the case, though the mechanism remains unknown. Experiments are in progress to determine whether heat or depolarization are involved.

Further study is needed to define the time between sperm entry into the egg and the zona reaction. In mating experiments with rats, Braden et al. (1954) estimated this time to lie somewhere between $10 \mathrm{~min}$ and $2 \mathrm{hr}$. From their observations on hamster ova, Barros \& Yanagimachi (1971) estimated that the zona reaction develops less than 15 min after cortical granule breakdown. Our studies show that approximately $8 \mathrm{~min}$ of this time is needed for the protease released from these granules to render the zona pellucida impenetrable to spermatozoa.

Note added in proof

A trypsin-like protease was recently found in the cortical granules of sea urchin eggs and the suggestion was made that it may be involved in the elevation of the fertilization membrane (Vacquier, Epel \& Douglas, 1972, Nature, Lond. 237, 34).

\section{REFERENCES}

Austin, G. R. \& BRADEN, A. W. H. (1956) Early reactions of the rodent egg to spermatozoon penetration. F. exp. Biol. 33, 358.

BARRos, C. \& YANAGMachi, R. (1971) Induction of zona reaction in golden hamster eggs by cortical granule material. Nature, Lond. 233, 268.

Braden, A. W. H., Austin, C. R. \& David, H. A. (1954) The reaction of the zona pellucida to sperm. Aust. F. biol. Sci. 7, 391. 
Conrad, K., Buckley, J. \& Stambaugh, R. (1971) Studies on the nature of the block to polyspermy in rabbit ova. . R. Reprod. Fert. $27,133$.

Gwatkin, R. B. L. (1964) Effect of enzymes and acidity on the zona pellucida of the mouse egg before and after fertilization. F. Reprod. Fert. 7, 99.

Gwatkin, R. B. L. (1966) Effect of viruses on early mammalian development. III. Further studies concerning the interaction of Mengo encephalitis virus with mouse ova. Fert. Steril. 17, 411.

Gwatkrn, R. B. L. (1971) Studying the effect of viruses on eggs. In: Methods in Mammalian Embryology, Chap. 14. Ed. J. C. Daniel. Freeman, San Francisco.

Gwatkin, R. B. L., Andersen, O. F. \& Hutchison, C. F. (1972) Gapacitation of hamster spermatozoa in vitro: the rôle of cumulus components. F. Reprod. Fert. 30, 389.

Gwatkin, R. B. L. \& WiLliams, D. T. (1970) Inhibition of sperm capacitation in vitro by contraceptive steroids. Nature, Lond. 227, 182.

Hartmann, J. F. \& Gwatkin, R. B. L. (1971) Alteration of sites on the mammalian sperm surface following capacitation. Nature, Lond. 234, 479.

Mares-Guta, M. \& Shaw, E. (1965) Studies on the active center of trypsin: The binding of amidines and guanidines as models of the substrate side chain. J. biol. Chem. 240, 1579.

Smrthaerg, M. (1953) The effect of different proteolytic enzymes on the zona pellucida of mouse ova. Anat. Rec. 117, 554.

TARkowski, A. K., Witkowska, A. \& NowickA, J. (1970) Experimental parthenogenesis in the mouse. Nature, Lond. 226, 162. 